\title{
Water Erosion in the Moulouya Watershed and its Impact on Dams' Siltation (Eastern Morocco)
}

\author{
Abdelkader Sbai ${ }^{1}$, Omar Mouadili ${ }^{1}$, Mohamed Hlal ${ }^{1}$, Khadija Benrbia ${ }^{1}$, Fatima Zahra Mazari ${ }^{2}$, \\ Mostafa Bouabdallah ${ }^{1}$, and Abdelouahid Saidi ${ }^{3}$ \\ ${ }^{1}$ Department of Geography, Mohammed Ist University, 60000, Oujda, Morocco \\ ${ }^{2}$ English Department, Mohammed Ist University, 60000, Oujda, Morocco \\ ${ }^{3}$ Department of Geography, Polydisciplinary Faculty of Taza, Taza, Morocco \\ Correspondence: Abdelkader Sbai (sbaiabdelkader59@gmail.com)
}

Published: 16 November 2021

\begin{abstract}
The Moulouya watershed presents high risks of water erosion. The dams built on this river lose each year, by siltation, a volume of water of about $10 \mathrm{M} \mathrm{m}^{3}$ (Lahlou, 1994). This worrying rate shows that water erosion can hinder the socio-economic development of the basin if soil protection and siltation measures are not taken. This study defines the areas most threatened by water erosion to protect them as a priority. Using a GIS and the Universal Earth Loss Equation (USLE), we mapped soil losses. The adopted model determines soil loss from erosivity of rainfall, soil erodibility, inclination and slope length, soil cover, and erosion control practices. The possible origins of the deposits alluviating the dams are related to the products of alteration of the Secondary's carbonate formations and the Tertiary and Quaternary formations. The modalities of the transport of deposits of banks of the network of Moulouya are mainly by a suspension. The specific degradation in the Moulouya watershed is estimated at $214 \mathrm{t} / \mathrm{km}^{2} /$ year. Precipitation intensity, steep slopes and deforestation are responsible for these losses.
\end{abstract}

\section{Introduction}

The degradation of natural resources by water erosion is one of the worrying risks that threaten human stability and is difficult to reduce. Moreover, it has been greatly exacerbated in recent years by the threat of the current dynamics, which could directly threaten food security and the population's health.

Water erosion in the Moulouya watershed has led to profound changes in various economic, social and environmental fields. It has led to the emergence of problems that can only be alleviated by integrated measures ensuring decent life for the population and preserving natural resources and sustainability for future generations. It presents a high risk and causes siltation of dams and significant losses of water volumes.

Therefore, the main issue of this research centres on the risk of water erosion, characterized by sheet flow, concentrated flow and gullying. All slopes are marked by erosion, especially sheet erosion which is responsible for the loss of significant amounts of soil and their deposition in dams. This erosion is governed by the nature of the fragile geological formations, especially the superficial quaternary formations, the nature of the sandy loam soil, the steep degree of the slopes, the slopes' dry exposure, and the type of land use (cultivation and overgrazing).

The main objective of this study is to assess the degree of soil degradation and highlight the degradation processes and systems concerning Man, which is a factor in the current imbalance of the environment. The study also aims to highlight the priority of protecting the areas most threatened by water erosion.

\section{The general geographical framework}

The Moulouya wadi is $520 \mathrm{~km}$ long; it rises in the High Atlas at an altitude of $2000 \mathrm{~m}$ and drains the largest watershed in Morocco $\left(57500 \mathrm{~km}^{2}\right)$. This basin located in the Orien- 


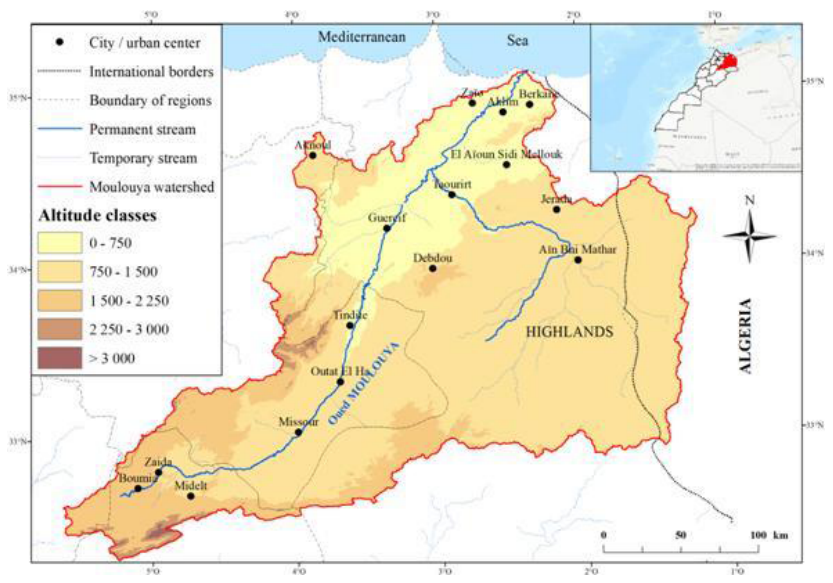

Figure 1. Location Map and the Moulouya Basin DEM (created by us based on layers of ASTER, GDEM, United States Geological Survey and https://www.openstreetmap.org/, last access: March 2021).

tal Region of Morocco (Fig. 1) presents a great diversity of morphological, climatic and socio-economic characteristics.

\subsection{A massive and rugged relief}

Young mountainous areas of high altitude (the eastern Rif, folded Middle Atlas, Beni Bou Yahi, Beni Snassen, High Atlas) and high plateaus (Highlands, Jerada chain) surround wide plains: Middle Moulouya, Guercif basin, Taourirt-El Aïoun corridor, Mediterranean plains. The mountain ranges inside the Moulouya basin are quite high and peak at $1839 \mathrm{~m}$ for the Beni Bou Yahi, $1535 \mathrm{~m}$ for the Beni Snassen, and $1726 \mathrm{~m}$ for the Jerada range. $18 \%$ of the watershed exceeds $1500 \mathrm{~m}$ a.s.l., and $11 \%$ is less than $500 \mathrm{~m}$. The Highlands go west to Moulouya. These vast entablatures of sedimentary rocks rest on an old base (Oran Meseta). The plains of Moulouya are large basins filled with detrital deposits.

The Middle and High Atlas and the mountains located inside the basin are predominantly limestones (especially Lias and Upper Jurassic). Sedimentary rocks (limestones, marls, sandstones and conglomerates) occupy $97 \%$ of the watershed's surface, while magmatic and metamorphic rocks cover only $3 \%$.

\subsection{A Mediterranean climate with differentiated seasons}

The Moulouya basin is a particularly arid region. It is located far from the humidifying and softening Atlantic influences and behind the mountainous screen formed by the Atlas and the Rif. Consequently, the climate becomes increasingly arid as one heads south. It is characterized by hot, dry summers and cool winters, with limited precipitations to winter periods. Total rainfall reaches more than $400 \mathrm{~mm}$ on average per year in the North and mountain areas, while in the South, it varies between 200 and $300 \mathrm{~mm}$ per year (Table 1).

\subsection{Diverse vegetation}

The Moulouya basin has a natural forest whose area was estimated in 2008 at 2.5 million hectares, or about $29 \%$ of the total area of national forests (Royaume du Maroc, 2015). The alfa covers most of these forests: 2.2 million hectares. The aridity explains the generally poor nature of the plant cover, which comes in two main forms. On the one hand, natural forest formations, more or less degraded, are located on certain relatively rainy mountain slopes where the holm oak and thuja are largely dominated. On the other, steppe formations are extending mainly through the arid spaces of the center and the South of the region where alfa and sagebrush dominate.

Population growth and the high demand for cultivable land have led to the clearing of rangelands, which are unsuitable for agriculture.

\subsection{An important hydrographic network with disturbed flow}

Oued Moulouya is by far the main river in the Oriental region. Its average flow is estimated at $41 \mathrm{~m}^{3} / \mathrm{s}$ at MechraHamadi $\left(85 \mathrm{~m}^{3} / \mathrm{s}\right.$ in April and $7.4 \mathrm{~m}^{3} / \mathrm{s}$ in August, a month of low water). It has an even more irregular regime as it crosses more humid mountain regions and vast semi-desert plains and plateaus. The flows can exceed $6000 \mathrm{~m}^{3} / \mathrm{s}$ in the Lower Moulouya River. Three large dams have been built in this basin to provide for the region's needs in terms of drinking water, irrigation and electricity production.

- Machrâa Hammadi dam built in 1956 on the Moulouya River with a height of $56 \mathrm{~m}$; it has a holding volume of 6.6 million $\mathrm{m}^{3}$ (42 million $\mathrm{m}^{3}$ at the start) currently.

- Mohammed V dam commissioned in 1967 with a height of $64 \mathrm{~m}$, is the largest water reservoir in the region, with currently a reservoir volume of 411 million $\mathrm{m}^{3}$ (760 million $\mathrm{m}^{3}$ at the start).

- Hassan II dam holding volume varies between 109 and million $\mathrm{m}^{3}$ with a flow of $710 \mathrm{~m}^{3} / \mathrm{s}$ during the rainy period and $450 \mathrm{~m}^{3} / \mathrm{s}$ during summer. It was put in the water in 2000 .

\subsection{Population and land use}

The population of the Moulouya basin exceeds 800000 inhabitants according to the General Census of Population and Housing of 2014, while the total area of irrigated land is around 110784 hectares, or $9 \%$ of the total area of agricultural land (MI.DGCL, 2015). The northern part, composed mainly of irrigated land, constitutes the first agricultural area of the region (Trifa plain). The other irrigated lands are located in the other plains of the region and near-certain urban agglomerations (Guercif, Taourirt...). As for the agricultural land in Bour, it extends over large areas exceed- 
Table 1. Monthly variations in rainfall: 1963-1999 (Météorologie nationale, Oujda, Maroc).

\begin{tabular}{lrrrrrrrrrrrrr}
\hline & J & F & M & A & M & J & J & A & S & O & N & D & Total \\
\hline Taforalt & 57 & 65 & 75 & 70 & 55 & 18 & 2 & 3 & 21 & 37 & 53 & 59 & 512 \\
Midelt & 17 & 18 & 27 & 33 & 29 & 12 & 4 & 4 & 18 & 19 & 23 & 16 & 220 \\
\hline
\end{tabular}

ing 635000 hectares. In the arid regions, livestock on natural rangelands constitutes the only possible source of agricultural income for the population of these regions. Cultivation techniques are an important anthropogenic factor that can either reduce or accelerate erosion. These various factors lead to intense erosion. The contributions of solid matter arriving in the dams were estimated at more than $10 \mathrm{M} \mathrm{m}^{3} /$ year (Lahlou, 1994).

\section{Tools and working methods}

First, the various studies related to the subject were consulted (Sadiki, 2005; Sbai and Ghzal, 2007). Subsequently, documents and data to describe the basin were used:

- The topographic maps at the 250000 -scale covering the basin, the geological maps (Oujda at 1/500 000), the vegetation map of the Waters and Forests (1/132000), then the soil map of Morocco (1/1000 000), in order to produce thematic maps;

- The numerical model of precipitation and temperature "WorldClim" was also used in order to calculate the precipitation aggressiveness index;

- "Landsat" and "Sentinel" satellite images, in order to study the degradation of plant cover and land use;

- The "Alaska" Digital Elevation Model, in order to study the topography of the basin;

- The precipitation data for several stations were used to know the rainfall and thermal regimes of the basin.

A quantitative approach was adopted to estimate soil loss using the Empirical Soil Loss Model to calculate the extent of soil degradation. Field measurements using the RAMP rain simulator have also been made (Roose, 1996). The universal soil loss equation (Wischmeier and Smith, 1978) is written as follows:

- $A=R \times K \times \operatorname{LS} \times C \times P$

- $A$ : The average annual soil loss ( $\mathrm{t} / \mathrm{ha} / \mathrm{year})$,

- $R$ : the rainfall erosivity factor,

- $K$ : the soil erodibility factor,

- LS: index combining the effect of the slope length factor and the slope steepness factor

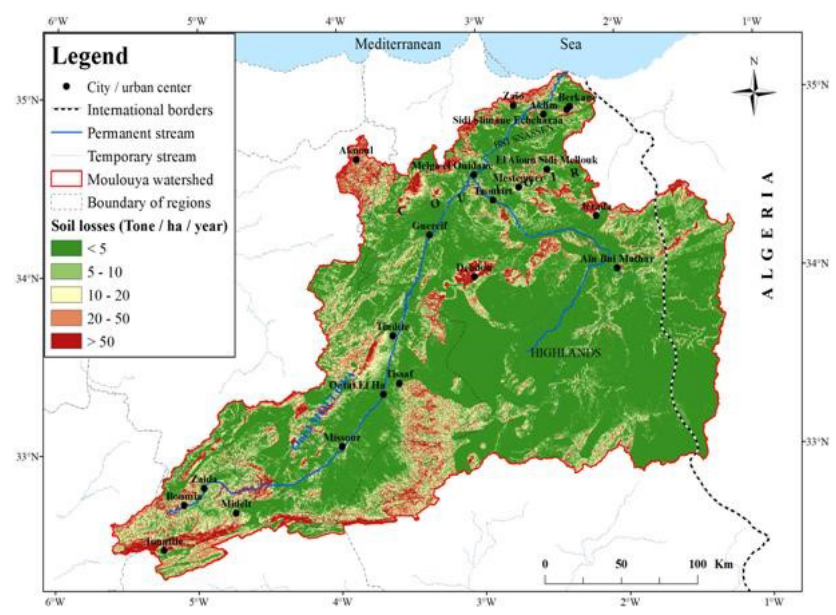

Figure 2. Soil erosion map (created by us based on layers of https: //www.openstreetmap.org/, last access: March 2021).

- $C$ : the cover management factor,

- $P$ : the supporting practice factor.

Climate erosivity is represented by $R$ and can be estimated by the rainfall intensity and amounts data. The soil erodibility monograph can be used to predict the $K$ value. The $L$ and $S$ factors characterize the topography and hydrology effects on soil loss. For direct USLE applications, a combined LS factor was evaluated for each land cell. Land use and management are represented by $P$ and can, with some difficulty, be inferred using remote sensing combined with ground-trusting (Sbai and Mouadili, 2021).

\section{Results and discussion}

The forms of current dynamics in the Moulouya basin are dominated by water erosion. This erosion is responsible for the loss of soil significant quantities and their deposit in dams. However, it is also governed by the nature of the geological formations and, especially, by the quaternary surface formations, the nature of the soil, the degree of slope, the orientation of the slopes, and the type of land use.

After calculating the various factors adopted in the universal soil loss equation, we calculated the areas of eroded land (Fig. 2).

In Fig. 2, we have tried to extract the amount of soil loss by dividing it into five categories according to the nature and morphological structure of the study area, and then we have 
Table 2. Quantities and areas of soil losses (created from the Fig. 2).

\begin{tabular}{lrrrrr}
\hline Class & Soil loss (tones/ha/year) & Quantity in tones/year & $\%$ & Area in km & $\%$ \\
\hline Very weak & $<5$ & 751086 & 8 & 39398 & 65 \\
Low & $5-10$ & 695067 & 8 & 7968 & 13 \\
Middle & $10-20$ & 934785 & 10 & 5639 & 9 \\
Strong & $20-50$ & 1515485 & 17 & 4279 & 7 \\
Very strong & $>50$ & 5145537 & 57 & 3119 & 5 \\
\hline Total & & 9041960 & 100 & 60403 & 100 \\
\hline
\end{tabular}

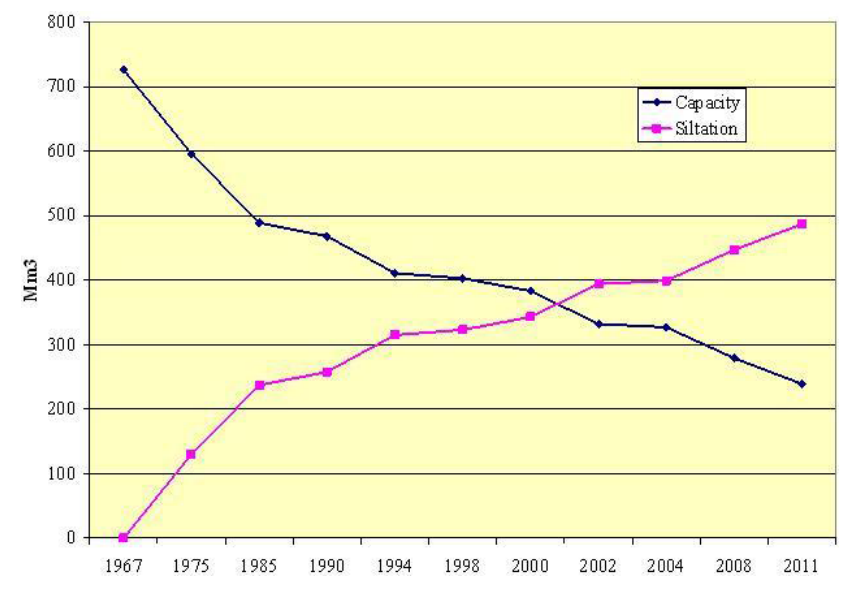

Figure 3. Photo 1: Extension of agricultural space and its removal by stone removal, which contributes to erosion (Evolution of Mohammed V dam's siltation (Agence du Bassin Hydraulique de la Moulouya, Oujda, Maroc)).

drawn up a table that indicates the quantity of soil loss categories (Table 2).

From the diagnosis of the manifestations of erosion and its quantification by modeling and by direct measurements in the field, we discovered that the degradation had reached complex and advanced levels.

The average soil loss is $3.86 \mathrm{~mm}$ thick per year, or 37.64 tonnes/ha/year. Direct field measurements show that the material removed varies from 0.02 to 29.05 tons per hectare. By generalizing these values to the annual averages of the stations in the study area, we obtain an average soil loss of 39.18 tonnes/ha/year.

The areas with high erosion represent $7398 \mathrm{~km}^{2}$ out of a total of $60402 \mathrm{~km}^{2}$; it is estimated at more than 6660000 tons per year. $74 \%$ of the materials removed are distributed over only $12 \%$ of the basin area. The average specific soil degradation in the basin is estimated at 13.5 tons/ha/year. Erosion values are relatively high in the Northwest (Msoun basin), in the Cretaceous marly limestones in the Southeast of Outat El Haj, in Hight Moulouya (Midelt region) and in some plains in the center. The quantities of eroded soil (less than 10 tons/ha/year) represent $16 \%$

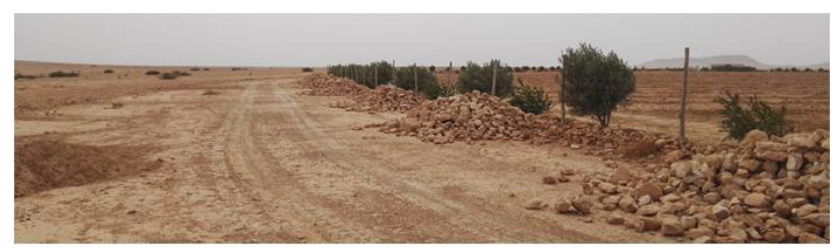

Figure 4. Evolution of Mohammed V dam's siltation (Extension of agricultural space and its removal by stone removal, which contributes to erosion (1 August 2017, national road no 19. Plain of Tafrata)).

of the area of the basin. They are estimated at more than 1446153 tons per year spreading over $78 \%$ of the basin.

The excessive and violent precipitations, the decline and degradation of the vegetation cover as well as the overexploitation of pastures and agriculture contribute to increase vulnerability and accelerate the development of the dynamics of water erosion. The soil is constantly deteriorating due to the rocky nature of the region and the natural conditions of drought, compounded to inadequate systems of human exploitation and degradation. Recent changes in land use have modified the spatial distribution of sediment feeding areas (Sbai and Ghzal, 2007).

Field observation clearly shows that agricultural work has extremely low production. Farmers are trying to gain more land at the expense of plant cover, which plays an important role in providing fodder for livestock and protecting the soil from water and wind erosion. This extension in inappropriate places causes erosion (Photo 1).

What is interesting is that the forms of degradation prevail in the absence of a global approach considering the needs and requirements of the rural population, whose absence in development projects and programs constitutes a major turning point for natural components and their importance for the preservation of natural resources and their sustainability.

The intense erosion processes in the Moulouya basin explain the high siltation rates of the Mechrâa Hammadi (1958) and Mohamed V (1967) dams and affect the irrigation of the Lower Moulouya river and the supply of drinking water for the main cities and urban centres of North-eastern Morocco. The evolution of siltation of the Mohamed V dam since 1967 shows that the reservoir has been subject to in- 
creasing sedimentation at variable speeds and an average rate of $10.8 \mathrm{M} \mathrm{m}^{3} /$ year, representing a capacity loss of $67 \%$. Figure 3 illustrates the temporal evolution of siltation.

\section{Conclusions}

The Moulouya basin experiences strong morphodynamical activity. Runoff develops on all slope classes and is intricately linked to the nature of the inappropriate exploitation of the fragile natural environment. Water erosion leads to the gullying and lateral extension of the valleys, which contributes to the removal of significant parts of the surface.

Thus, in this study, we have tried to evaluate the amount of soil loss by the universal Wischmeier equation and carry out direct measurements on experimental plots to show the magnitude of the current erosive dynamics. Field observations show that the transport of deposits by the various rivers is essentially due to suspension. This mode of transport can affect particles smaller than $400 \mu \mathrm{m}$. The remaining fraction is transported by saltation. These sediments are trapped in dams and explain the significant loss of water volumes.

It is necessary to seek this degradation's prospects and follow its evolution concerning local resources and the human factor, which is an essential element of the environment current imbalance.

Data availability. The data are available upon request (sbaiabdelkader59@gmail.com).

Author contributions. AS, OM, MB and AS carried out the rain simulation experiments in the field. $\mathrm{OM}, \mathrm{KB}$ and $\mathrm{MH}$ took care of the data processing and the production of the maps. AS wrote the text with contributions from all the co-authors. FZM revised the text from a language point of view.

Competing interests. The contact author has declared that neither they nor their co-authors have any competing interests.

Disclaimer. Publisher's note: Copernicus Publications remains neutral with regard to jurisdictional claims in published maps and institutional affiliations.
Special issue statement. This article is part of the special issue "Hydrology of Large River Basins of Africa". It is a result of the 4th International Conference on the "Hydrology of the Great Rivers of Africa", Cotonou, Benin, 13-20 November 2021.

Acknowledgements. The authors would like to express their sincere and profound recognition to Mr. Mohamed DELLAL, Professor Emeritus of English at Mohammed First University in Oujda for his proofreading.

\section{References}

Lahlou, A.: Envasement des barrages au Maroc. Collection "Sciences et techniques" de la Faculté des Lettres et des Sciences Humaines: Série Thèses et Mémoires, Wallada, 1994.

Royaume du Maroc: Ministère de l'Intérieur, Direction Générale des Collectivités Locales (2015) - La Région de l'Oriental, Monographie générale, 66 pp., 2015.

Roose, E.: Land Husbandry: Components and Strategy, FAO Soils, Bulletin 70, Food and Agriculture organization of United Nations, Rome, 1996.

Sadiki, A.: Estimation des taux d'érosion et de l'état de dégradation des sols dans le bassin versant de Boussouab, Maroc Nord Oriental: Application du modèle empirique (USLE), de la technique du radio-isotope ${ }^{137} \mathrm{Cs}$ et de la susceptibilité magnétique " Thèse pour l'obtention du grade de Docteur d'Etat en géologie, l'Université Mohammed Premier, Faculté des Sciences, Oujda, 2005.

Sbai, A. et Ghzal, M.: Dégradation des parcours et érosion dans le couloir d'El Aioun - Taourirt (Maroc nord-est), Colloque National: Taourirt - Oued Za - la Kasbah. Histoire, espace et développement, 8-9 Mai 2007, Province de Taourirt, Travaux du Colloque, Collection Etudes \& Séminaires, (en langue arabe), 169-182, 2007.

Sbai, A.: et Mouadili, O.: Le risque d'érosion hydrique entre fragilité des équilibres environnementaux et perspectives de durabilité: Cas du bassin versant d'oued El Abed, Maroc, Revue marocaine des Sciences Agronomiques et Vétérinaires, Vol. 9 No 4 (2021): (Décembre 2021), Soumis: avr 5, 2021, Publiée: déc 15, 2021. https://www.agrimaroc.org/index.php/Actes_ IAVH2/issue/view/83, 2021.

Wischmeier, W. H. and Smith, D. D.: Rainfall energy and its relatioship to soil loss, Trans. AGU 39, 285-291, 1958. 